http://www.diva-portal.org

\title{
Postprint
}

This is the accepted version of a paper published in . This paper has been peer-reviewed but does not include the final publisher proof-corrections or journal pagination.

Citation for the original published paper (version of record):

Englund, L., Arnberg, F K. (2018)

Survivors' experiences of journalists and media exposure: A retrospective qualitative study 15 years after a ferry disaster

Disaster Prevention and Management

https://doi.org/10.1108/DPM-02-2018-0056

Access to the published version may require subscription.

N.B. When citing this work, cite the original published paper.

Permanent link to this version:

http://urn.kb.se/resolve?urn=urn:nbn:se:kau:diva-69232 
Survivors' Experiences of Journalists and Media Exposure: A Retrospective Qualitative Study Fifteen Years after a Ferry Disaster

Liselotte Englund

Karlstad University
Filip K. Arnberg

Uppsala University

\section{Author Note}

Liselotte Englund, Risk Management, Department of Environmental and Life Sciences, Faculty of Health, Science and Technology, Karlstad University, Karlstad, Sweden.

Filip Arnberg, National Centre for Disaster Psychiatry, Department of Neuroscience, Psychiatry, Uppsala University, Uppsala, Sweden. E-mail: filip.arnberg@ neuro.uu.se 


\begin{abstract}
Purpose The media is an important part of disaster management, yet little is understood about their interplay with the disaster survivors. This study aimed to examine disaster survivors' long-term retrospective views of their experiences with journalists and the media coverage.
\end{abstract}

Design Twenty-two Swedish adult survivors (of 49 eligible) from a ferry disaster in the Baltic Sea, in which only 137 of the 989 people onboard survived, were interviewed after 15 years about their experiences of meeting journalists in the immediate aftermath and the media coverage in a long-term perspective. The transcribed interviews were analyzed using qualitative content analysis.

Findings Survivors from the Estonia ferry disaster described a wide array of experiences from their contacts with the disaster journalists and being exposed in the media. From their experiences, four categories were extracted. The categories were common for both their media contacts and their media exposure: strain, support, rationality, and evasion. The survivors' experiences were both negative and positive.

Research implications These accounts of disaster survivors' experiences from an event 15 years ago provide an interesting comparison for future studies of contemporary disasters.

Originality/value This study provides important perspectives on the role of disaster coverage in the media and documents how disaster survivors retrospect on the media as both a burden and a resource.

Keywords: Disasters; Survivors; Media exposure; Media management; Media ethics; Reporters; Trauma journalism; Qualitative content analysis 


\section{MEDIA IN DISASTERS}

\section{Introduction}

Disasters and large-scale incidents generate intensive and widespread media coverage. In the immediate aftermath, reporters and photographers seek to interview survivors, who often suffer from acute stress (Englund, 2008, Englund et al., 2014) and the reporting often spans across several years. Disaster management teams have plans that may include advice or explicit strategies on media communication (Englund et al., 2012), and crisis support plans sometimes include recommendations for how to support survivors who are to be interviewed by journalists (Brymer et al., 2006). As of yet, however, there is very little empirical data to draw from when formulating these strategies.

The independent media serves an important part of disaster communications, providing people with timely information and in-depth reporting. The reporting can contribute to the creation of meaning for the survivors and the general population (Tuchman, 1973, Olofsson, 2011) and even provide examples of adaptive behaviors (Garner, 1996). The journalistic narrative naturally involves a selection of voices, however, that can lead to an inadequate representation of an event. There have also been ethical transgressions by journalists and unethical editorial decisions about publications that have led to publicity damage (Office of the Press Ombudsman, 2001, Englund, 2008, von Krogh, 2016).

Careful planning of communication strategies may confer large benefits to the healthcare services (Englund et al., 2014, Englund et al., 2012). For disaster managers, the media can be used to their advantage. However, disaster preparedness is relevant also for the media houses. A review noted several shortcomings in the local media disaster preparedness in the USA (Quarantelli, 1996). Poor disaster preparedness among the media may lead to suboptimal methods used by their personnel when contacting disaster victims.

The follow-up by the media is pertinent to consider for disaster management. Disaster survivors survivors experience a wide array of emotions in the acute phase (van der Kolk et $a l ., 1996)$. The emotional turmoil is accompanied by perceptions of loss of control, integrity, autonomy, and predictability (Hobfoll et al., 2007). These immediate reactions can impair the survivors' judgement, and sometimes result in reality detachment (American Psychiatric Association, 2013). It is worth noting, however, that survivors are generally adaptive and active agents in their own recovery: they use coping strategies available to them to reduce their distress, seek social support, and help others (Bonanno, 2004). Nevertheless, intrusive journalists and insensitive reporting might intensify the survivors' aversive experiences. In the 


\section{MEDIA IN DISASTERS}

long term, the media coverage may influence the survivors' framing of the event and the response from the societal institutions. Several years after the event, increased media attention around disaster commemorations can give rise to transient stress reactions among the survivors and worsen the distress among those suffering from chronic trauma-related stress reactions (Arnberg et al., 2013).

A study after two train crashes in Sweden found that survivors sometimes perceive the interviews with the media as supportive (Englund et al., 2014). The survivors see it as a positive part of their recovery process to share what they have experienced, in order to help others to gain a greater understanding of the event (Cottle, 2013, Kay et al., 2010, Englund et al., 2014). A study from the 2011 terror attack in Norway corroborates these positive aspects of media encounters, although they also provide examples of negative experiences with the media (Glad et al., 2017). Similarly, in a study from the 2007 Virginia Tech school shooting, the major themes found in the survivors' and family members' included a lack of compassion from the journalists, but also experiences of sensitive journalists with genuine concern (Walsh-Childers et al., 2011). A study of victims from school shootings in Finland suggested that many who were interviewed by the media felt worse afterwards (Haravuori et al., 2011).

Because long-term follow-up studies are lacking, it is unclear whether the current knowledge capture the survivors' experiences of the media coverage and being exposed in the media beyond the first months. Such knowledge could inform disaster management teams in their media communications strategies and in their recommendations to both the personnel and the survivors. Despite the changing conditions for the media due to the rapid technological advances, there might be valuable lessons to learn from survivors' retrospective assessments of their encounters with journalists. In the present study, the primary aim was to examine the Swedish survivors' retrospective views of their experiences with journalists and the media coverage, including their own exposure in the media.

\section{Method}

\subsection{The Event}

In September 1994, a passenger and car ferry with 186 crew members and 803 passengers on board capsized in the Baltic Sea. The passengers and crew who could escape the ferry before it submerged floated for several hours in life rafts and boats in stormy weather. They were then saved onto other ferries or by rescue helicopters and taken to hospitals around the Baltic Sea where they were given acute medical care before being repatriated. In total, there were 


\section{MEDIA IN DISASTERS}

137 individuals who survived and 852 who perished (Joint Accident Investigation Commission of Estonia, 1997).

The media coverage was very extensive (Lauristin and Vihalemm, 1996, Hadenius et al., 1996, The Swedish Ministry of Enterprise and Innovation, 1999) and journalists could generally move freely among the survivors at the hospitals. Press conferences were held with survivors, starting the day after the disaster. After the survivors had been repatriated, they and their families were contacted by journalists at work, in public spaces, and in their homes. The general public perceived the media reporting to be too intrusive and extensive criticism was aimed at tabloid newspapers (Hadenius et al., 1996). The media reporting continued for a prolonged period of time, and the ten-year-commemoration received extensive media coverage.

\subsection{Procedure}

This study is part of a mixed-methods follow up of the survivors' experiences and mental health after the ferry disaster (Arnberg et al., 2011, Arnberg et al., 2013). Fourteen years after the disaster, all traceable Swedish survivors were sent a postal survey in which they were asked about participation in personal interviews. As there were only 49 eligible participants, all survivors were invited instead of using random or purposive sampling. Those who consented to interviews were invited 10 months later, with an opportunity to decline participation. The interviewer (FA) conducted the interviews in the participants' choice of location, most often their home, over the course of five months. The audiotaped interviews had a mean duration of 118 minutes (range $=85-164 \mathrm{~min}$ ). They were transcribed verbatim (Brinkmann and Kvale, 2014) by experienced administrative staff. No inconsistencies were found in a validation check of a subset of the transcriptions against the tapes. The participants provided written informed consent before the interviews. They did not receive any financial reimbursement or compensation. The study was approved by the Regional Ethical Review Board in Uppsala, Sweden.

\subsection{Participants}

The eligible participants included 49 survivors, of 51 Swedish survivors in total, who were invited to participate in the survey (one was deceased and one was not traceable). Thirty-four (69\%) survivors responded. Of these, 25 (74\%) consented to an interview. One participant later declined and two could not be reached. The final sample of 22 participants represented $45 \%$ of the original sample of survivors with a Swedish domicile. A comparison of 


\section{MEDIA IN DISASTERS}

participants and non-participants on demographic characteristics, traumatic bereavement, and previously reported posttraumatic stress levels suggested that a lower proportion of participants than non-participants were bereaved in the event and that the participants were, on average, less burdened by posttraumatic stress (Arnberg et al., 2013).

The final sample was predominantly male $(\mathrm{n}=17 ; 77 \%)$ with a median age of 54 years. Twelve participants (55\%) had completed university education. Fourteen participants (64\%) were cohabiting. Eighteen participants $(82 \%)$ were either working full time or had retired. They identified themselves as healthy and reported none or only one episode of extended sick leave throughout their school years and adult life. Few reported having been unemployed for any longer period, if at all. None reported any disaster-related physical injuries that were still bothering them. The majority had participated in a crisis group that held monthly meetings during the year after the event and partook once or more in annual meetings during the following 10 years. Five participants $(23 \%)$ had received therapy for severe stress reactions since the event.

\subsection{Measures and Analysis}

The interview included two sets of questions, after initially establishing rapport and collecting demographic data. The first set of questions were open-ended, designed for qualitative data analysis. This set included the following topics: the process of recovery, any potential longterm impact of the event on their daily lives, social support, coping strategies, receipt of interventions, and experiences with journalists and the media. Then followed a break, after which a structured clinical interview was conducted. In this study, we focus on the participants' experiences with the media; the other topics have been reported elsewhere (Arnberg et al., 2013).

The media-related questions were based on earlier research (Englund, 2000, Englund, 2002, Englund, 2008, Englund et al., 2014). Five questions related to specific guidelines in the professional Code of Ethics (Office of the Press Ombudsman, 2001) to probe the extent of which survivors thought that the media followed its professional standards. For example, "What was your experience of the journalists' presence at different sites, such as hospitals?" and, "To what extent did you experience that journalists showed due respect to you and others affected?" The participants provided media-relevant information in all parts of the interview, however, and so the corpus was reviewed in total with an inclusive approach by the second 


\section{MEDIA IN DISASTERS}

author for any items that might be relevant to the aim of the study. One item could consist of an utterance or one or more consecutive sentences.

The transcribed interviews were analyzed using qualitative content analysis (Graneheim and Lundman, 2004, Graneheim et al., 2017). The analysis was made by the first author, who holds a $\mathrm{PhD}$ in journalism studies and is well experienced in qualitative studies and trauma journalism. The text was read and re-read to acquire a broad overview of the participants' experiences. The content was divided into meaningful units that were condensed while preserving the core content. The condensed text was then abstracted and given codes, and a comparison was conducted within and across them. The text was subsequently sorted into separate subcategories. General categories were then formulated based on the whole text, including the content of subcategories and the original understanding of the text. The categorization was discussed between the authors in an iterative process. Quotations in the results are presented with fictitious names: Survivors of age 30-39 were assigned names starting with the letter A; a B for ages 40-49; C for ages 50-59; and D for $\geq 60$. In the excerpts provided below, the sign "..." indicate a short pause whereas " . .. /" indicate that content was excluded for sake of brevity. Examples of the content analysis can be seen in Table 1.

Table 1. Excerpt of the three levels in the content analysis.

\begin{tabular}{lll}
\hline Unit of Meaning & Subcategory & Category \\
\hline That press conference was a bit like letting people loose in the & Premature & Strain \\
town market ... and there are a lot of people who've just been & interviews & \\
shipwrecked ... and who have agreed to being interviewed. & & \\
(Bengt) & & \\
\hline
\end{tabular}

\section{Results}

The analysis generated four similar categories concerning the participants' experiences of interacting with journalists and their experiences of the media coverage. There were 17 subcategories: nine of experiences of meeting with journalists and eight of the media coverage (Table 2). The results show both similarities and a diversity of experiences from meeting the media and the media coverage. 
MEDIA IN DISASTERS

Table 2. Categorization of the survivors' experiences with meeting journalists and the media reporting and exposure.

\begin{tabular}{|c|c|c|c|}
\hline \multicolumn{2}{|l|}{ Categories } & \multicolumn{2}{|l|}{ Subcategories } \\
\hline Name & Description & $\begin{array}{l}\text { Theme: Meeting } \\
\text { journalists }\end{array}$ & $\begin{array}{l}\text { Theme: Media reporting } \\
\text { and media exposure }\end{array}$ \\
\hline Strain & $\begin{array}{l}\text { Journalist contact and } \\
\text { media experienced as } \\
\text { harmful }\end{array}$ & $\begin{array}{l}\text { - Premature interviews } \\
\text { - Unethical conduct }\end{array}$ & $\begin{array}{l}\text { - Loss of control } \\
\text { - Fear of media }\end{array}$ \\
\hline Support & $\begin{array}{l}\text { Journalist contact and } \\
\text { media as helpful and } \\
\text { useful }\end{array}$ & $\begin{array}{l}\text { - Journalist as therapist } \\
\text { - Social function } \\
\text { - Assembling a jigsaw } \\
\text { puzzle }\end{array}$ & $\begin{array}{l}\text { - Sense of coherence } \\
\text { - A box of memories } \\
\text { - Next of kin context }\end{array}$ \\
\hline Rationality & $\begin{array}{l}\text { Pragmatic, } \\
\text { instrumental approach } \\
\text { to journalists and } \\
\text { media }\end{array}$ & $\begin{array}{l}\text { - Interview as sign of life } \\
\text { - Appreciation of } \\
\text { profession and } \\
\text { situation }\end{array}$ & $\begin{array}{l}\text { - Help out for a cause } \\
\text { - Perceived duty to } \\
\text { inform }\end{array}$ \\
\hline Evasion & $\begin{array}{l}\text { Avoiding contact with } \\
\text { journalists and media }\end{array}$ & $\begin{array}{l}\text { - Active rejection } \\
\text { - Protective gatekeepers }\end{array}$ & - Detachment \\
\hline
\end{tabular}

\subsection{Meeting the Journalist}

The participants reported that the interviews took place in hospitals as well as at nearby airports shortly after the rescue operation. They described that follow-up interviews were carried out with them and with next-of-kin at hospitals, in their homes, or in public places for a prolonged time after the event. Many survivors participated in several Swedish and foreign media channels (e.g., newspapers, radio, television).

\subsubsection{Strain}

Premature interviews. Traumatized, shocked, and injured, individuals may have little chance to understand the consequences of an interview shortly after their rescue. An extra challenge was the survivors' meeting not with a single journalist, but with a massive media turnout. Intermediaries in the form of hospital staff between survivors and the media was no guarantee of protection. 


\section{MEDIA IN DISASTERS}

It was actually the hospital staff that said: 'can someone take some questions because the pressure on the hospital is so heavy.' In retrospect, I don't know if that was particularly wise. Sensible decisions are not made in situations like that. You can't get a grasp of what you have been involved in. (Bertil)

That press conference was a bit like letting people loose in the town market ... and there are a lot of people who've just been shipwrecked ... and who have agreed to being interviewed. (Bengt)

... in a very short time, the journalists had surrounded us. We each had a corner in the gym hall, the four of us who were to participate, with 20-30 photographers and reporters. $(\mathrm{Bo})$

Some participants found it unreasonable to expect that someone who had just survived a disaster should be able to consider the situation wisely and make reasonable assessments of what a media exposure may entail. They noted an imbalance in the relationship between survivors and the media; the survivor is weak and the press corps strong. Witnessing others being interviewed in a fragile state was upsetting, which sometimes highlighted their own vulnerability and nudged them towards declining interviews.

At that point, I didn't have a clear grasp of anything, so I consented /.../In retrospect I think that it's not fair to answer questions so soon after such an event. (Bertil)

But at that stage when you're so utterly weak, it's hard. I think they were ruthless, actually. (Britta)

I saw interviews with other survivors, how you respond in shock. You don't know what you answer ... you don't understand ... you don't understand what's going around you. (Barbro)

Unethical conduct. The participants noted several examples of unethical conduct, some approaches resembling undercover journalism. In contrast, several statements suggest that there was a great variation in the journalists' conduct

The whole media posse was standing there waiting for us when we disembarked in Helsingfors. /.../ And some media geezers burst in and said that they were relatives. The guards removed them. (Dexter)

... and then two persons came up and talked to me ... they were in hospital uniform ... then it turned out that they were journalists. (Dag) 


\section{MEDIA IN DISASTERS}

The journalists were bloody awful. They broke in there. /.../ They'll use any method. (Dylan)

I was pretty mad at the media, to be honest. /.../ Really hard to take. They really provoked me. (Britta)

Yes, a number of them more or less nagged their way in. I ended up in the Turku hospital. And they sent messages to me through the nurse. (Caesar)

There was a great difference, at least initially, between Swedish and international media /.../ German and French TV crews, for instance, approached us more ruthlessly. (Bo)

\subsubsection{Support}

Journalist as therapist. Suddenly meeting a person who had the time to listen was now perceived as supportive by many of the survivors, albeit in certain cases delusively so.

In a way, I got to tell the story ... and it was a form of therapy to me. It was good for me. It was my way coping with it. (Caesar)

Provided that the individual was capable of judging what could and should be said to the media, the interview was experienced as a positive event in several cases, especially in the relation to the thought that it had not taken place.

Actually, for the better almost, because there was someone more to talk to. (Billy)

They had a bloody fair approach there actually, as I had asked them to go to hell / .../

They asked what seemed to be adequate questions /.../ how I was and if they could help in any way. (Bo)

There are more examples of survivors who felt well treated by interviewing journalists and reporters who were considerate.

She had an extremely low profile. She barely dared to ask questions. I know that I was very thoughtful. (Dennis)

One person described the interview situation as a debriefing:

Then I make an interview, quite long, definitely 20-30 minutes. Only answered questions, talking to the camera. It was like a first debriefing, the first time I put it all together. (Bengt) 


\section{MEDIA IN DISASTERS}

Social function. The participants reported having received many invitations from the media in various contexts. For many, this was a valuable experience.

I got to travel around a bit with journalists .... I got to travel in Europe and have become more urbane. (Billy)

I thought it was good that I got out a bit. I met with other people, journalists. Many of them were really nice. (David)

Assembling a jigsaw puzzle. A frequent approach to the media reporting was seeing it as 'assembling a jigsaw puzzle'. Many survivors collect clippings, and radio and TV segments, creating coherence and explaining course of events.

When I met journalists who asked good questions, I also felt good about it ... Answering the questions and getting the story together. It was good. (Ann)

\subsubsection{Rationality}

Interview as sign of life. A reflection of the year of the disaster is the many examples of how TV broadcasts were used as a communication channel between relatives and friends.

[Journalists from TV-news] were there in the evening /... / then we thought that it would be good for the family at home to see us ... that we were alive and could report on things. (Caesar)

... we thought ... it must be good to be on TV a little so that the family at home could see that we were alive ... because I hadn't talked with my wife at the time, so she didn't know anything. (Bo)

So many were wondering what had happened. Of course, it was important to talk about it and try to sort it out. (Billy)

Appreciation of profession and situation. Several of those who were extensively exposed in the media viewed this as something natural. Even when the journalists seemed to transgress rules, the participants expressed an understanding of the journalists' working conditions, which also encompassed entrenched hospital staff.

Journalists, they are also human beings. There were examples of everything from trying to bribe their way into the hospital to behaving perfectly normally. (Ann) 


\section{MEDIA IN DISASTERS}

Outside, there was such a pressure on the staff that were supposed to protect us ... that they asked us for help. This put both us and the staff in a situation we couldn't really handle. (Bertil)

\subsubsection{Evasion}

Active rejection. A relatively large proportion of the survivors chose actively to decline requests to participate in media activities, in the acute phase and in the long term.

I have stayed away from the media. I.../ Someone has phoned but I've said no every time. (Didrik)

They pushed microphones and cameras into our faces ... and I didn't say anything, just stood there smoking ... and then they sour on me for not answering questions. (Bo)

Protective gatekeepers. Deliberate or not, the police and the hospital staff in many cases functioned as intermediaries between survivors and the media. In some cases, the participants felt that the staff were pressured into the form of gatekeepers, a role they had difficulties to sustain.

At the hospital ... the police were there and they escorted me out through the backdoor ... and made sure I didn't come into contact with any journalists. (Barbro)

At the hospital it was very protected and comfortable, and I wasn't interested in them [journalists] at all. (Ann)

Well, it was as if the hospital staff would be beaten because they were coming to film (Bo)

A nurse asked me if I had the strength to help out. (Dan)

The counsellor or the hospital chaplain said that they wanted to see me but I said no (Dennis)

\subsection{Media Reporting and Media Exposure}

\subsubsection{Strain}

Loss of control. There were associations between the loss of control during the disaster and the media participation, and how stressful it was to read about the media happy endings, which few survivors could relate to. 


\section{MEDIA IN DISASTERS}

... that the ship was sinking I had no control of ... then it continued, then things I couldn't control kept happening. Perhaps that's why I was so provoked. (Britta)

There was a happy-ending story with two survivors and I know I was terribly angry. /.../ ... and then I felt that two who had a happy-ending and the rest of us did not. (Britta)

Fear of media. Some described the encounter with the media flow and sight of reporters and photographers in terms of a phobia, which has led to fear of newspaper posters and cameras. Someone remarked that certain media consumption, for example, extremely intimate humaninterest journalism, still today triggers stress reactions.

I can still be afraid when I see people with the big camera lenses to zoom in on something ... that's horrible ... those sounds "click, click". (Ann)

\subsubsection{Support}

Sense of coherence. Many participants pointed to the media as important to understand the time course of the event and to grasp what had happened and the meaning of it all.

I tried to understand how it happened and so on ... plus I read all newspaper articles and every media production on the subject that I could get hold of. (Bo)

... then it was a source of information on what had happened for me. (Bo)

Box of memories. Collecting media reports seemed to have been some kind of therapy to many, and the total volume of clippings seemed to become proof that the unthinkable had happened. For most participants it became an unopened box in the attic or a chest of drawers, sometimes being overwhelming.

I have a box in the attic with all the papers ... and I haven't read anything, (Berit)

A friend saved everything and it's in the attic and I still haven't looked at it. (Britta)

I became obsessed in some way because I had to see everything and read everything I came across. /.../ And if there was something on TV I had to record it ... I felt impelled to. What I was to do with it, I don't know. (Dagmar)

Next of kin context. Some participants who had collected press clippings believed that the collection was of more significance to their next of kin than to themselves, sometimes primarily for future use. They felt that their next of kin had a need of information from the media both during the acute phases and in the long term. Several participants mentioned how important the media reports were for their families. 


\section{MEDIA IN DISASTERS}

My husband wanted to watch TV more ... he needed to understand. I remember that I always went off to do the dishes or something. (Berit)

I have a lot and I think that it will be for my children and grandchildren ... if they should want to write a book someday. But I don't think that I'll go through it. (Britta)

\subsubsection{Rationality}

Help out for the cause. Some participants described rational assessments on the possible benefits of participating, grounded in a sense of duty to help out.

We were sitting in a waiting room and far away I heard some journalists asking the Finnish police or whoever if there was someone they could talk to. 'No', he said. Then I said that I thought I had a pretty good picture of what had happened and I'm just sitting here waiting so I can talk to them. (Billy)

There was this press conference that the hospital management had announced, and they asked us patients if we could consider partaking in an interview and I did. (Bo)

In retrospect, I can feel ... that I said more positive things than what I actually felt in the bubble I was in, that I wanted to seem stronger than I really was, you know. But the media were not to blame /.../It was my choice and I didn't feel that they were intrusive either. But the thing is, you tend to adjust your answer to the situation all the time. (Adrian)

Perceived duty to inform. The participants declined many requests from media outlets. Nevertheless, they also responded to many interviews as they felt a duty to inform and share their own experiences with others.

Many asked what had happened. Of course, it was important to give an account of it. (Billy)

What would I have liked to know if this had happened [to someone else]? I have always been thinking along those lines a bit, wanting to know when things happened, and that's why we agreed then too, for this reason. (Caesar)

\subsubsection{Evasion}

Detachment. Avoiding certain impressions to alleviate external pressure as a form of coping was frequent in the interviews. 


\section{MEDIA IN DISASTERS}

I know that when I went from [one] hospital to [another hospital], I saw all the newspaper posters and they were all about the Estonia /.../ and it was very hard. /.../It was as if I never wanted to hear about Estonia again. (Britta)

I only really read what was in [a daily newspaper]. I never read the tabloids. (Didrik) One participant asked an acquaintance who was a mental health professional for advice on how to relate to the intensive coverage:

\section{I asked: 'Should I read this?' But he said: 'No, don't'. (Dennis)}

This recommendation stayed with him. He had not looked at the collected clippings since they were bundled up in 1994.

\section{Discussion}

The survivors from the Estonia ferry disaster described a wide array of experiences from their contacts with the journalists and their exposure in the media. We found four common categories in their experiences: strain, support, rationality, and evasion. The categories strain and evasion describe negative aspects of these experiences, the category support indicate clearly positive aspects, and the category rationality describe an instrumental approach.

The experiences of the media as both positive and negative seem to be a consistent finding in the literature (Kay et al., 2010, Englund et al., 2014), which is linked with another consistent finding, that initial contacts with the media are perceived as more negative than later contacts (Englund et al., 2014, Glad et al., 2017, Roxberg et al., 2010, Kay et al., 2010, Vasterman et al., 2005, Hawkins et al., 2007). In this study, the experiences did take on somewhat different expressions for personal meetings with reporters and photographers as compared to the media coverage. The strain in the meeting with reporters correspond to previous findings, in which survivors described a helplessness and vulnerability towards journalists and photographers, as well as being provoked by the presence of the media (Englund et al., 2014). After the terror attacks in Norway, 2011, the survivors perceived the journalists as disrespectful, intrusive, inconsiderate, and disrespectful (Glad et al., 2017). Similar experiences were found among survivors from bus crashes in Sweden (Doohan and Saveman, 2014) and school shootings in Finland (Haravuori et al., 2011). Being covered in the media has also been noted as a risk of an additional burden on the victims (Jemphrey and Berrington, 2010). 


\section{MEDIA IN DISASTERS}

Negative experiences of media interviews may influence the survivors' perceptions of the media coverage. The coverage of the Estonia ferry disaster was burdensome to several survivors, in one case leading to a fear of the media. The aversion of media coverage of the event, or other similar events, has been noted previously (Englund et al., 2014), and may either reflect the survivors' appraisal of the media specifically or represent one aspect of traumatization.

A recurring finding is that survivors describe positive experiences in relation to the media (Glad et al., 2017, Englund et al., 2014, Kay et al., 2010). A study of the 2007 school shooting at Virginia Tech in the U.S.A. found that a majority of the youth were positive towards interacting with the media. Despite examples of them perceiving the media as being insensitive and lacking compassion, there were many examples of responsive and compassionate reporters (Walsh-Childers et al., 2011). In this study, however, appreciative comments about the journalist as a therapist, or mentions of interviews and press conferences as "a first debriefing", raise concerns about over-disclosure. Nonetheless, the survivors' further support-seeking behaviors might increase if they feel supported in their first retelling of their experiences.

The media coverage may also provide a sense of coherence and provide a context for social support (Peterson, 2006), as well as a coherent and understandable picture of otherwise very complex events (Englund et al., 2014). The inclusion of the survivors' stories in the media coverage may provide a richer coverage, of benefit to the other survivors and their social networks (Cottle, 2013). However, this would not be the case if the reporting were one-sided or false. In a follow-up study of the 2011 terror attack in Norway, no association could be found between the survivors' perceptions of the media and their burden of posttraumatic stress (Thoresen et al., 2014).

A significant proportion of disaster survivors describe a neutral stance towards the journalists' presence at the site and the media coverage. This is expressed in a rational view on the role of the media and their own participation, or in an active distancing (i.e., evasion) from one's own participation and the general media coverage (Englund et al., 2014). The survivors' own participation in interviews is explained as "helping out for the cause", using the media as a way of mass communication, and to minimize the number of repetitions of one's story (Glad et al., 2017, Gearing, 2013). 


\section{MEDIA IN DISASTERS}

The survivors' descriptions highlight the importance of preparations among the healthcare and crisis support personnel. It seemed easier for survivors to make choices with regard to the timing and content of interviews if they were supported by personnel. Indeed, using gatekeepers seemed to have conferred such benefits after the 2011 terror attack in Norway (Englund et al., 2012).

\subsection{Limitations}

The findings should be interpreted in light of several limitations. First, the prolonged hiatus between the event and the interviews might have brought about a shift in perspectives and evaluations of the early post-disaster events, and there is an unknown degree of recall bias. The survivors' reports may bear relevance nonetheless. Their reports of the event correspond well to public records of early interviews made available by the authorities (The Swedish Ministry of Enterprise and Innovation, 1999). Some aspects of this study may be outdated, however, due to the technological changes in the past decades. Social media is not accounted for in this study, although this arena raises questions about ethical conduct among journalists (Simon et al., 2016).

As for the representativity of the sample, the participants comprised a fair coverage of different experiences and posttraumatic stress levels (Arnberg et al., 2013). This follow-up study probed mental health issues: although participation might have been conditioned on current mental health status, there was a low risk that participants declined participation due to particular views on the media. There is a risk of experimenter bias, as one interviewer conducted all interviews due to practical reasons. The risk is reduced by the fact that another researcher analyzed the transcripts. Finally, the 1994 Estonia ferry disaster was followed by a pervasive, and later criticized, media coverage (The Swedish Ministry of Enterprise and Innovation, 1999). Although disasters often receive intensive coverage, potential differences in coverage between events should be taken into account when interpreting the findings.

\subsection{Conclusions}

Several years after the disaster, the survivors describe how they mindfully navigated the immediate aftermath and made decisions that they thought were beneficial to themselves and their close ones. They provide rational deliberations about the need for information and communication from the media. The positive aspects suggest that completely disallowing interviews with survivors might neglect the positive consequences of them having active voices in the media narrative. 


\section{MEDIA IN DISASTERS}

Gatekeepers may nonetheless be needed between journalists and survivors to prevent ethically dubious conduct. These intermediaries should be aware of potential positive aspects of the survivors' media experiences, as they may not be readily understood by disaster management teams. Among the survivors themselves, their families and friends, and also among the society as a whole, the media represents an important source of information and a part of a collective crisis response.

\subsection{Implications}

Comprehensive and clear guidelines for media relations may mitigate negative aspects of disaster survivors' experiences. They would include, for example, clear descriptions of important personnel functions, such as for gatekeepers, and encompass both structured situations (e.g., press conferences) and unstructured events (e.g., individual meetings between survivors and journalists). Within the training of disaster management teams, we suggest that the education on disaster communication includes the perspectives of the survivors and the media. The modes of communication are rapidly changing, and so regular updates to any such guidelines are needed.

The present study indicates further research into the mapping of disaster survivors' experiences of the media. A larger body of empirical studies is needed to better understand in what ways the survivors' interactions with the media can be mutually positive, and for whom, and in what situations, such interactions would be associated with long-term negative perceptions of the event and its consequences.

\section{References}

American Psychiatric Association (2013), Diagnostic and Statistical Manual of Mental Disorders, 5th edition, American Psychiatric Publishing, Arlington, VA.

Arnberg, F.K., Eriksson, N.-G., Hultman, C.M. and Lundin, T. (2011), "Traumatic bereavement, acute dissociation, and posttraumatic stress: 14 years after the MS Estonia disaster", Journal of Traumatic Stress, Vol. 24 No. 2, pp.183-90. Arnberg, F.K., Hultman, C.M., Michel, P.O. and Lundin, T. (2013), "Fifteen years after a ferry disaster: clinical interviews and survivors' self-assessment of their experience", European Journal of Psychotraumatology, Vol. 4 No. 1, 20650.

Bonanno, G.A. (2004), "Loss, trauma, and human resilience: have we underestimated the human capacity to thrive after extremely aversive events?", American Psychologist, Vol. 59 No. 1, pp.20-8. 


\section{MEDIA IN DISASTERS}

Brinkmann, S. and Kvale, S. (2014), InterViews: learning the craft of qualitative research interviewing, 3 edition, Sage, Los Angeles, CA.

Brymer, M., Jacobs, A., Layne, C., Pynoos, R., Ruzek, J., Steinberg, A., Vernberg, E. and Watson, P. (2006), Psychological First Aid: Field Operations Guide, 2nd edition, National Child Traumatic Stress Network and National Center for PTSD, Los Angeles, CA.

Cottle, S. (2013), "Journalists witnessing disaster", Journalism Studies, Vol. 14 No. 2, pp.23248.

Doohan, I. and Saveman, B.I. (2014), "Impact on life after a major bus crash--a qualitative study of survivors' experiences", Scandinavian Journal of Caring Sciences, Vol. 28 No. 1, pp.155-63.

Englund, L. (2000), "The journalistic work: experiences from a difficult mission [Swedish]". In: Larsson, L. \& Nohrstedt, S.A. (eds.) The Gothenburg Fire 1998: A Study of Communication, Rumours, and Trust, Stockholm, Sweden, Styrelsen för psykologiskt försvar, pp. 159-90.

Englund, L. (2002), "Media at the scene: a study of the interplay between journalists and rescue services during crisis [Swedish]", P21-404/02, Swedish Rescue Services Agency, Karlstad, Sweden.

Englund, L. (2008), The Eye of the Disaster: A Study of Journalists' Work at the Site of the Event [Swedish], The Department of Journalism, Media and Communication, University of Gothenburg, Gothenburg, Sweden.

Englund, L., Forsberg, R. and Saveman, B.-I. (2014), "Survivors' experiences of media coverage after traumatic injury events", International Emergency Nursing, Vol. 22 No. 1, pp.25-30.

Englund, L., Michel, P.-O., Riddez, L. and Örtenwall, P. (2012), "The bomb attack in Oslo and the shootings at Utøya, 2011 [Swedish]", Kamedo Report No.97, The National Board of Health and Welfare, Stockholm, Sweden.

Garner, A.C. (1996), "Reconstructing reality: interpreting the aeroplane disaster news story", Disaster Prevention and Management: An International Journal, Vol. 5 No. 3, pp.515.

Gearing, A. (2013), "Why disaster survivors speak to reporters ", Australian Journalism Review, Vol. 35 No. 1, pp.71-81.

Glad, K.A., Thoresen, S., Hafstad, G.S. and Dyb, G. (2017), "Survivors report back", Journalism Studies, Vol. 19 No. 11, pp.1-17. 


\section{MEDIA IN DISASTERS}

Graneheim, U.H., Lindgren, B.M. and Lundman, B. (2017), "Methodological challenges in qualitative content analysis: a discussion paper", Nurse Education Today, Vol. 56, pp.29-34.

Graneheim, U.H. and Lundman, B. (2004), "Qualitative content analysis in nursing research: concepts, procedures and measures to achieve trustworthiness", Nurse Education Today, Vol. 24 No. 2, pp.105-12.

Hadenius, S., Hedman, L. and Nowak, K. (1996), "Estonia in the News [Swedish]", Report No. 168:3, Styrelsen för psykologiskt försvar, Stockholm, Sweden.

Haravuori, H., Suomalainen, L., Berg, N., Kiviruusu, O. and Marttunen, M. (2011), "Effects of media exposure on adolescents traumatized in a school shooting", Journal of Traumatic Stress, Vol. 24 No. 1, pp.70-7.

Hawkins, N.A., Mcintosh, D.N., Silver, R.C. and Holman, E.A. (2007), "Early responses to school violence: a qualitative analysis of students' and parents' immediate reactions to the shootings at Columbine high school", Journal of Emotional Abuse, Vol. 4 No. 3-4, pp.197-223.

Hobfoll, S.E., Watson, P., Bell, C.C., Bryant, R.A., Brymer, M.J., Friedman, M.J., Friedman, M., Gersons, B.P.R., De Jong, J.T.V.M., Layne, C.M., Maguen, S., Neria, Y., Norwood, A.E., Pynoos, R.S., Reissman, D., Ruzek, J.I., Shalev, A.Y., Solomon, Z., Steinberg, A.M. and Ursano, R.J. (2007), "Five essential elements of immediate and mid-term mass trauma intervention: Empirical evidence", Psychiatry: Interpersonal and Biological Processes, Vol. 70 No. 4, pp.283-315.

Jemphrey, A. and Berrington, E. (2010), "Surviving the media: Hillsborough, Dunblane and the press", Journalism Studies, Vol. 1 No. 3, pp.469-83.

Joint Accident Investigation Commission of Estonia, Finland and Sweden (1997), Final report on the capsizing on 28 September 1994 in the Baltic Sea of the ro-ro passenger vessel MV Estonia, Edita, Helsinki, Finland.

Kay, L., Reilly, R.C., Connolly, K. and Cohen, S. (2010), "Help or harm? Symbolic violence, secondary trauma and the impact of press coverage on a community", Journalism Practice, Vol. 4 No. 4, pp.421-38.

Lauristin, M. and Vihalemm, P. (1996), "Estonia: the disaster in Estonian media", Report No. 168:5, Styrelsen för psykologiskt försvar, Stockholm, Sweden.

Office of the Press Ombudsman (2001), "Code of Ethics for Press, Radio and Television in Sweden", available at http://po.se/about-the-press-ombudsman-and-press- 


\section{MEDIA IN DISASTERS}

council/code-of-ethics-for-press-radio-and-television-in-sweden/ (accessed 21

December 2017).

Olofsson, A. (2011), "The Indian Ocean tsunami in Swedish newspapers: nationalism after catastrophe", Disaster Prevention and Management, Vol. 20 No. 5, pp.557-69.

Peterson, A. (2006), "Remembering loss and sharing grief. The Gothenburg fire disaster in a collective memory perspective [Swedish]", Research report 136, Dept. of Sociology, Gothenburg University, Sweden, Gothenburg, Sweden.

Quarantelli, E.L. (1996), "Local mass media operations in disasters in the USA", Disaster Prevention and Management, Vol. 5 No. 5, pp.5-10.

Roxberg, Å., Burman, M., Guldbrand, M., Fridlund, B. and Barbosa Da Silva, A. (2010), "Out of the wave: the meaning of suffering and relieved suffering for survivors of the tsunami catastrophe. An hermeneutic-phenomenological study of TV-interviews one year after the tsunami catastrophe, 2004", Scandinavian Journal of Caring Sciences, Vol. 24 No. 4, pp.707-15.

Simon, T., Goldberg, A. and Adini, B. (2016), "Are ethical norms and current policies still relevant in face of the recent mass terror events?", Scandinavian Journal of Trauma, Resuscitation and Emergency Medicine, Vol. 24 No. 1, pp.118.

The Swedish Ministry of Enterprise and Innovation (1999), "Learning from Estonia [Swedish]", SOU 1999:48, The Swedish Government, Stockholm, Sweden.

Thoresen, S., Jensen, T.K. and Dyb, G. (2014), "Media participation and mental health in terrorist attack survivors", Journal of Traumatic Stress, Vol. 27 No. 6, pp.639-46.

Tuchman, G. (1973), "Making news by doing work: routinizing the unexpected", American Journal of Sociology, Vol. 79 No. 1, pp.110-31.

Van Der Kolk, B.A., Mcfarlane, A.C. and Weisæth, L. (1996), Traumatic stress: the effects of overwhelming experience on mind, body, and society, Guilford Press, New York, NY.

Vasterman, P., Yzermans, C.J. and Dirkzwager, A.J.E. (2005), "The role of the media and media hypes in the aftermath of disasters", Epidemiologic Reviews, Vol. 27 No. 1, pp.107-14.

Von Krogh, T. (2016), Media Ethics: Emergence, Function, Future [Swedish], Studentlitteratur, Lund.

Walsh-Childers, K., Lewis, N.P. and Neely, J. (2011), "Listeners, not leeches: what Virginia Tech survivors needed from journalists", Journal of Mass Media Ethics, Vol. 26 No. 3, pp.191-205. 